\title{
COESÃO E COERÊNCIA EM PRODUÇÕES TEXTUAIS DE UNIVERSITÁRIOS
}

\section{COHESION AND COHERENCE IN TEXTUAL PRODUCTIONS OF ACADEMIC STUDENTS}

\author{
Rosimari Lorenz Martins \\ Universidade Feevale \\ rosel@feevale.br \\ Cíntia de Moura Pinto \\ Universidade Feevale \\ cintiademourap@feevale.br
}

RESUMO: Este trabalho discute a coesão e a coerência em textos produzidos por universitários participantes de um curso intitulado "Como começar e como terminar um comentário escrito?", oferecido gratuitamente pela Universidade Feevale/RS. Os objetivos deste estudo foram investigar se os textos apresentavam problemas de coesão e coerência e averiguar quais os problemas mais recorrentes, tomando como base as metarregras de Charolles (2002). Para tanto, foram analisados oito textos de oito participantes do curso. A análise revelou que os textos produzidos apresentaram inadequações, especialmente, no que diz respeito à Mr1.

PALAVRAS-CHAVE: Linguística textual. Metarregras. Textualidade.

ABSTRACT: This work discusses the cohesion and the coherence in texts produced by academic students who have done "Como começar e como terminar um comentário escrito?" course, offered by Universidade Feevale/RS for free. The goals of this study were to investigate whether the texts presented cohesion and coherence problems and find out which were the most recurrent issues, based on Charolles' (2002) metarules theory. Therefore, had been analyzed eight texts from eight participants of the course. The analysis have shown that the texts have presented inadequacies, especially about MR1.

KEYWORDS: Textual linguistics. Metarules. Textuality. 


\section{Introdução}

Assim como o galo, com seu canto, não tece sozinho a manhã, o texto precisa do entrelaçamento de palavras, de ideias e de sentidos para que ser inteligível. Um bom texto necessita de elementos que o tornem algo dotado de significação, tanto visual quanto subjetivamente, ainda que a leitores desacostumados possam passar despercebidos.

Por se tratar de um objeto de intenção comunicativa, o texto pode apresentar diversas abordagens e temáticas, porém, para que se produza e, consequentemente, possa ser entregue ao mundo, é necessário que a palavra escrita seja articulada de tal maneira que o que precisa ser dito seja dito e compreendido e que as sutilezas e intenções do enunciador descortinem nuances até o desconhecido revelar-se. Mas, para isso, é importante que se saiba quais são os aspectos fundamentais que regem um texto bem-sucedido e o que é preciso fazer para produzir um bom texto.

Pesquisas de diversos teóricos do texto e do discurso salientam a importância dos aspectos semântico e pragmático para a produção textual como determinantes para a pertinência do texto, além da necessidade de atentar para a função social da atividade verbal. Assim, o texto agregado a aspectos interacionais e socioculturais torna-se parte de um grande emaranhado no processo de organização da comunicação.

É preciso estar ciente, entretanto, de que o texto é mais do que um agrupamento de palavras para se atingir um fim. Ele é o objeto da língua em uso. Por meio da palavra escrita, é possível circular pelos mais variados ambientes sociais, portanto, a habilidade de uso da escrita também é um indicador de grupos sociais mais desenvolvidos. Planejar, organizar e elaborar um texto que alcance seu intento comunicativo, contudo, demanda conhecimento e estratégias de desenvolvimento da escrita.

Nessa perspectiva, desenvolveu-se este trabalho, cujo objetivo geral foi verificar se as produções textuais de alunos de ensino superior, realizadas em um curso de extensão da Universidade Feevale/RS, direcionado ao desenvolvimento da competência discursiva na modalidade escrita, contemplam os aspectos essenciais que um texto deve apresentar para ser bem compreendido. Objetivou-se, também, (i) investigar se os textos apresentam problemas de coesão e coerência e (ii) averiguar quais os problemas mais recorrentes, com base nas metarregras de coerência de Charolles (2002), que não desvincula os elementos coesivos dos de coerência, mas entende que coesão e coerência estão intrinsecamente ligadas como partes constituintes do sentido do texto. 
Para tanto, foram analisados oito (8) textos de oito (8) participantes do curso "Como começar e como terminar um comentário escrito?", do Projeto de Extensão LAVILI - Laboratório de Vivências em Linguagem - Português, da Universidade Feevale/RS.

\section{Concepções de texto e de textualidade}

$\mathrm{O}$ conceito de texto dá-se de acordo com a perspectiva teórica que o fundamenta. Desde o início da linguística do texto até os dias atuais, ele foi visto de maneiras distintas. A princípio, concebia-se texto como uma estrutura com início, meio e fim, de modo que era analisado por seu próprio processo de formação.

Com o advento da análise pragmática do texto, passou-se a considerá-lo como produto parcial do funcionamento da comunicação, associado a elementos socioculturais e de interação entre emissor e receptor, tornando-o, assim, parte de um complexo mais elaborado no sistema de organização da comunicação. Para tanto, a prática comunicativa compreende métodos, funções e táticas que, na mente humana, desencadeiam ações de interação social.

Segundo Val (1999, p. 3), "pode-se definir texto ou discurso como ocorrência linguística falada ou escrita, de qualquer extensão, dotada de unidade sociocomunicativa, semântica e formal". Assim, o texto é uma atividade verbal com função social, de modo que, por estar inserido em contextos mais intrincados, requer objetivos específicos de ação e escolha adequada para se alcançar sua compreensão, ou seja, necessita de uma atividade intencional do emissor em conformidade com a situação na qual é produzido, para que o receptor, por meio de uma manifestação verbal, compreenda seus propósitos.

Desse modo, trata-se de uma ação interacional, pois o emissor e o receptor interagem e estão ligados na ação da produção textual. Pode-se dizer, então, que o texto é o resultado de uma interação verbal entre indivíduos inseridos em determinado contexto social, no qual alinham suas ações de modo a atingir um objetivo social de acordo com a circunstância. Segundo Koch (2000, p. 22),

poder-se-ia, assim, conceituar o texto como uma manifestação verbal constituída de elementos linguísticos selecionados e ordenados pelos falantes, durante a atividade verbal, de modo a permitir aos parceiros, na interação, não apenas a depreensão de conteúdos semânticos, em decorrência da ativação de processos e estratégias de ordem cognitiva, como também a interação (ou atuação) de acordo com práticas socioculturais. 
Já a construção de sentido no texto dá-se pelo equilíbrio e pela disposição das informações semânticas e por, pelo menos, dois importantes aspectos: o dado e o novo. $\mathrm{O}$ dado são as informações preexistentes na bagagem consciente dos interlocutores. Ele serve para a retomada de inferências ou referências textuais, nas quais o emissor prepara terreno para o novo. As cadeias coesivas desempenham papel fundamental na organização do texto, pois tomam parte na produção de sentido no que toca à retomada de conhecimentos prévios do receptor e o prepara para a progressão de informações, o novo,

[...] estabelecendo-se, assim, as relações de sentido entre: a) segmentos textuais de extensões variadas; b) segmentos textuais de conhecimentos prévios; c) segmentos textuais e conhecimentos e/ou práticas socioculturalmente compartilhados [...] (KOCH, 2000, p. 24).

O texto só tem sentido e legitimidade se inserido em um contexto de situação comunicativa. Portanto,

um texto se constitui enquanto tal no momento em que os parceiros de uma atividade comunicativa global, diante de uma manifestação linguística, pela atuação conjunta de uma complexa rede de fatores de ordem situacional, cognitiva, sociocultural e interacional, são capazes de construir, para ela, determinado sentido (KOCH, 2000, p. 25).

Dessa maneira, entende-se que o texto em si não tem sentido, mas que o sentido é construído a partir do texto, a partir da interação com o texto. Inúmeros são os meios e as táticas para se chegar ao que está implícito e subjacente no que toca ao sentido.

A partir do momento em que "um - e não o - sentido" (Koch, 2000, p. 25) se estabelece, as adequações relativas à interação comunicativa e à compreensão entre os parceiros de comunicação fazem com que ocorra a coerência textual. O "jogo de linguagem", em uma situação concreta e válida de atividade verbal, leva os interactantes a identificar um tex to como texto.

Dessa forma, entende-se que o texto "designa toda e qualquer manifestação da capacidade textual do ser humano [...] isto é, qualquer tipo de comunicação realizado através de um sistema de signos" (FÁVERO; KOCH, 2005, p. 26). O texto fundamenta-se, então, independentemente de sua extensão, em passagens faladas ou escritas que são dotadas de um todo significativo, de modo que o texto seja 
uma unidade de sentido, [...] um contínuo comunicativo contextual que se caracteriza por um conjunto de relações responsáveis pela tessitura do texto - os critérios ou padrões de textualidade, entre os quais merecem destaque especial a coesão e a coerência (FÁVERO; KOCH, 2005, p. 26).

O texto é uma unidade de linguagem de uso, que cumpre a função de interação comunicativa. Segundo Koch e Travaglia, (2004, p. 8), o texto é

uma unidade linguística concreta (perceptível pela visão ou audição), que é tomada pelos usuários da língua (falante, escritor/ouvinte, leitor), em uma situação de interação comunicativa, como uma unidade de sentido e como preenchendo uma função comunicativa reconhecível e reconhecida, independentemente da sua extensão.

Segundo Beaugrande (1997), "um texto não existe como texto, a menos que alguém o processe como tal". Dessa forma, consoante Koch (2003, p. 154),

[...] os princípios de textualização deixam de ser vistos como critérios ou padrões que um texto deve satisfazer, mas como um conjunto de condições que conduz cognitivamente à produção de um evento interacionalmente comunicativo. Isto é, os sete padrões de textualidade propostos em Beaugrande \& Dressler (1981) não são critérios que permitem identificar as fronteiras entre um texto e um não texto, mas sim as condições para uma ação linguística, cognitiva e social na qual eles operam como modos de conectividade em níveis diversos, mas inter-relacionados.

Nessa perspectiva, textualidade, conforme Val (1999), são as características que tornam o texto um texto, ou seja, por textualidade, entende-se uma ação comunicativa (sequência linguística) e não somente um aglomerado de palavras ou de frases soltas. Tal sequência é reconhecida como um texto no instante em que o receptor a entende como um todo pleno de significado.

Um texto, contudo, não traz sentido em si mesmo, ele tem de ser significado tanto por quem produz o discurso quanto por quem o recebe, de modo que cada texto poderá ter diversas interpretações, porque pode ser textualizado de maneiras diferentes por ouvintes e leitores diferentes. Assim, a textualidade é um princípio geral que faz parte do conhecimento que os falantes têm sobre texto e que os leva a aplicar um conjunto de fatores capazes de textualizar todas as produções que leem, ouvem, falam ou escrevem. A textualidade não está nos textos, ela é um componente do saber linguístico das pessoas. 
Os fatores que constituem a textualidade, segundo Beugrande e Dressler (1981), e que as pessoas aplicam aos textos que escrevem e esperam encontrar nos que leem, são sete: coerência, coesão, intencionalidade, aceitabilidade, situacionalidade, informatividade e intertextualidade.

A coerência, segundo Val (2004), é aquilo que faz com que o texto pareça lógico, consistente, com sentido. Consegue-se entender um texto, de acordo com a pesquisadora, quando é possível atribuir coerência a ele. A coerência está relacionada com as

'ideias' do texto, com os conceitos e as relações entre conceitos que esse texto põem em jogo: de que tópicos o texto fala, o que diz sobre eles, como organiza e articula esses tópicos (por exemplo, com relações de causa/consequência, ou de anterioridade/simultaneidade/posterioridade, ou de inclusão/exclusão, ou de semelhança/oposição, ou proximidade/distância) (VAL, 2004, p. 3).

A coesão, consoante a mesma pesquisadora, diz respeito ao "inter-relacionamento entre os elementos linguísticos do texto" (VAL, 2004, p. 5) e, de acordo com Fávero (2006, p. 10), "a coesão, manifestada no nível microtextual, refere-se aos modos como os componentes do universo textual, isto é, as palavras que ouvimos ou vemos, estão ligados entre si dentro de uma sequência”. Dessa forma, coesão é o modo como as estruturas se expressam no aspecto formal do texto. Ela pode ser gramatical ou lexical. A coesão gramatical refere-se ao uso de elementos correlacionais que proporcionam não só a ligação entre as palavras mas também entre as frases e as sequências de frases em um texto. Já a coesão lexical dá-se pela reiteração (recuperação de algum item léxico por ideia expressa, substantivação), substituição (quando há expressões linguísticas com traços semelhantes, opostos ou de mesma relação) e associação (a relação de palavras pertencentes ao mesmo esquema cognitivo, que podem referir-se ao mesmo evento).

A intencionalidade é o que o emissor deseja alcançar com seu discurso em determinada situação comunicativa. Ela depende de uma construção coesa e coerente dando, assim, valor ilocutório ao discurso.

A aceitabilidade refere-se à receptividade com que o texto é defrontado. Ela permite perceber o potencial de cooperação com o objeto do emissor e se o texto leva o recebedor a agregar conhecimentos. Nesse jogo, o produtor pode, deliberadamente, apresentar diferentes abordagens, que alterem a pertinência do discurso (por exemplo, piadas). Essas abordagens dependem do grau de formalidade e da tolerância entre os locutores na interação comunicativa. 
A situacionalidade diz respeito ao valor do texto quanto às circunstâncias e ao contexto em que se dá a situação sociocomunicativa. É a adequação do texto para determinado sentido do discurso.

A partir desses três últimos fatores, espera-se que o produtor do texto tenha ciência do quanto pode esperar do recebedor em nível de conhecimento anterior, de tal modo que, por exemplo, uma informação inicialmente descabida tenha sentido para quem a recebe de acordo com seu conhecimento preliminar. Essa é a concepção de coerência pragmática, na qual o texto deve ser percebido pelo recebedor como natural em determinado contexto.

A composição dos mais variados tipos de discurso vem a calhar no que toca a certas intenções ilocucionais, de maneira que há tipos particulares de texto para cada situação/circunstância e que são convenientes para o funcionamento da linguagem na interação sociocomunicativa. Nesse contexto, a informatividade refere-se ao grau de informatividade e, por conseguinte, diz respeito ao coeficiente de previsibilidade do texto, para que o recebedor tenha interesse nele ou não. Ela se divide em dois pontos: a imprevisibilidade e a suficiência de dados. Quanto menos previsível o texto for, mais informativo ele se torna, porque a novidade, em nível mediano, é cativante. $\mathrm{O}$ estranhamento absoluto quanto ao contexto ou à intenção comunicativa, entretanto, acarreta rejeição. A suficiência de dados, por outro lado, são as informações dadas que o texto deve apresentar para se tornar compreensível de acordo com a pretensão do produtor.

A intertextualidade configura a relação entre o discurso e o conhecimento prévio do recebedor. As ligações de sentido dependem e só se efetivam perante o encadeamento de informações anteriormente dadas. A intertextualidade pode ser de forma ou de conteúdo (KOCH; TRAVAGLIA, 2004). A intertextualidade de forma ocorre quando o produtor do texto retoma, de maneira proposital, trechos, expressões ou enunciados de outros textos que, ao serem desencadeados, recuperam ideias e sejam o ponto de partida para o reconhecimento do que já é sabido e se encontram em "blocos mentais". Um exemplo disso tem-se na "Canção do Exílio", de Gonçalves Dias, e no "Canto de regresso à pátria", de Oswald de Andrade.

A intertextualidade de conteúdo decorre do diálogo entre textos de um mesmo grupo específico, como áreas do conhecimento ou de interesse. Isso pode ser observado quando matérias jornalísticas tratam do mesmo fato em destaque de determinado período, por exemplo, e realizam um diálogo, retomando textos anteriores. À retomada de textos próprios para dialogar com textos que seguem dá-se o nome de intratextualidade. 
A coesão textual, segundo Koch (1999, p. 17), dá-se pelo entrelaçamento de enunciados e partes de enunciados que assinalam determinadas relações de sentido. "É por meio de mecanismos como estes [...] que se vai tecendo o 'tecido' (tessitura) do texto". Conforme Marcuschi (1983 apud KOCH, 2000, p. 94), "os fatores de coesão são aqueles que dão conta da sequenciação superficial do texto, isto é, os mecanismos formais de uma língua que permitem estabelecer, entre os elementos linguísticos do texto, relações de sentido".

Koch (2000) considera para análise duas modalidades de coesão: a remissão e a sequenciação. A remissão consiste no uso de recursos de ordem gramatical (pronominalizações, numerais, artigos definidos, advérbios pronominais) ou lexical (sinônimos, elipses, reiterações), da (re)ativação de referentes e da referenciação anafórica e catafórica. Essas sinalizações são válidas porque servem de suporte ao interlocutor para o processamento textual, como pode ser visto no exemplo que segue (KOCH, 2000, p. 37), observando-se as marcações em itálico:

(1) A jovem acordou sobressaltada. Ela não conseguia lembrar-se do que havia acontecido e como fora parar ali; (2) Márcia olhou em torno de si. Seus pais e seus irmãos observavam-na com carinho; (3) Desejo somente isto: que me deem a oportunidade de me defender das acusações injustas; (4) O enfermo esperava uma coisa apenas: o alívio de seus sofrimentos (KOCH, 2000, p. 37).

No que toca aos constituintes remissivos, pode ocorrer coesão dotada de ambiguidade, por isso, "havendo, no contexto, dois ou mais referentes potenciais para uma forma remissiva, a decisão do leitor/ouvinte terá de se basear nas predicações feitas sobre elas, levando em conta todo o contexto em que estão inseridas [...]" (KOCH, 1999, p. 48).

A coesão sequenciadora é a que possibilita o avanço das relações semânticas do texto, desde que se assegure a progressão e a continuidade do sentido.

O sequenciamento de elementos textuais pode ocorrer de forma direta, sem retornos ou recorrências; ou podem ocorrer na progressão do texto recorrências das mais diversas ordens: de termos ou expressões, de estruturas (paralelismo), de conteúdos semânticos (paráfrase), de elementos fonológicos ou prosódicos (similicadência, rima, aliteração, assonância) e de tempos verbais (KOCH, 2000, p. 40-41).

Koch $(1999$, p. 49) elucida que a progressão textual pode se dar por elementos recorrentes ou não. Em função disso, ela subdivide esse tópico em 
sequenciação frástica (em que não há recorrência estrita) e sequenciação parafrástica (com procedimentos de recorrência). A sequenciação frástica ocorre pelo encadeamento sucessivo em que marcas linguísticas se estabelecem compondo o texto de maneira clara "sem rodeios ou retornos que provoquem um 'ralentamento' no fluxo informacional” (KOCH, 1999, p. 55).

Os principais recursos para a sequenciação frástica são os conectores, entre os quais se encontram as conjunções, os advérbios, entre outros, que propiciam o desdobramento do texto e são formados por marcas linguísticas entre os enunciados do texto e que estabelecem determinados tipos de relação. A sequenciação frástica, segundo Koch $(1999$, p. 60), é constituída pelos procedimentos de manutenção temática, pela progressão temática e pelo encadeamento que "permite estabelecer relações semânticas e/ou discursivas entre orações, enunciados ou sequências maiores do texto".

A manutenção temática engloba o uso de elementos pertencentes ao mesmo campo lexical, de continuidade semântica ou "colocação", de modo que um esquema cognitivo se ative na memória do receptor e ele entenda esses elementos como gatilhos para a interpretação e avance para o que deve vir na sequência do texto, como mostra o exemplo que segue, em que a manutenção temática é garantida pelas palavras "acidentes", "ambulâncias", "vítimas" e "hospital". "O desabamento de barreiras provocou sérios acidentes na estrada. Diversas ambulâncias transportaram as vítimas para o hospital da cidade mais próxima" (KOCH, 1999, p. 57).

A progressão temática diz respeito à questão da articulação tema/rema, desenvolvida pelos linguistas da Escola Funcionalista de Praga, à hierarquização das unidades semânticas. Nessa hierarquização, o tema é tudo aquilo que se toma como base da comunicação e o rema é o que se diz sobre o tema. Como mostra o exemplo extraído de Koch (1999, p. 58): "O cão é um animal mamífero e quadrúpede. (tema) Ele tem o corpo coberto de pelos. (rema) O cão é um excelente guarda para nossas casas (rema). (O) É um animal muito fiel. (rema)".

O encadeamento, por sua vez, "permite estabelecer relações semânticas e/ ou discursivas entre orações, enunciados ou sequências maiores do texto. Pode ser obtido por justaposição ou por conexão" (KOCH, 1999, p. 60).

A sequenciação parafrástica dá-se por meio da reiteração de termos veiculadores de ideias (de um mesmo item lexical, sem que haja, contudo, uma identidade total de sentido, porque cada um deles traz novas instruções de sentido); de estruturas sintáticas (preenchidas com itens lexicais diferentes); de conteúdo semântico (que pode ser introduzido por expressões linguísticas 
como, isto é, ou seja, ou melhor, quer dizer); de recursos fonológicos (existência de uma invariante, como igualdade de metro, ritmo, rima, assonâncias, aliterações); e de tempo e aspecto verbal. A coerência textual, por sua vez, está ligada à possibilidade de estabelecer o sentido de um texto. Assim, para que um texto seja coerente, ele precisa ser interpretável. Um texto é coerente quando apresenta uma continuidade semântica e quando todos os enunciados produzidos pertencem à mesma unidade comunicativa. A coerência depende das relações de sentido que se estabelecem, de forma explícita, entre as palavras. Essas relações devem obedecer a três princípios: o princípio da relevância, que exclui a representação de situações que não estejam relacionados entre si; o princípio da não contradição, que exclui a representação de situações logicamente incompreensíveis; e o princípio da não redundância, segundo o qual um texto não pode ser nulamente informativo.

Além disso, cabe destacar, ainda, que a coerência textual depende da progressão temática, que diz respeito à introdução da informação nova que faz evoluir o texto, da continuidade semântica, que se dá por meio da recorrência da informação que assegura a unidade do texto, e da pontuação, que também é fundamental para a coerência do texto.

Existem quatro tipos de coerência: a semântica, a sintática, a estilística e a pragmática. A coerência semântica refere-se à relação entre os significados dos elementos das frases em sequência. A incoerência, nesse caso, aparece quando esses sentidos não combinam ou quando são contraditórios. A sintática refere-se aos meios sintáticos usados para expressar a coerência semântica, tais como, conectivos, pronomes etc. A coerência pragmática refere-se ao texto visto como uma sequência de "atos de fala" (AUSTIN, 1985). Para haver coerência pragmática, os atos de fala que a constituem devem satisfazer as mesmas condições presentes em uma dada situação comunicativa. E a coerência estilística, por fim, é uma noção relacionada à mistura de registros linguísticos, que não chega, todavia, a perturbar a interpretabilidade do texto. A coerência, portanto, é um fenômeno que resulta da ação conjunta de todos esses tipos e de sua influência na produção do sentido do texto.

Nessa perspectiva, para analisar o texto, do ponto de vista dos elementos que estabelecem e determinam as relações de sentido, Val (1999) considera a análise textual a partir dos critérios de continuidade, progressão, não contradição e articulação.

A continuidade, na coerência, dá-se na permanência, na retomada de ideias no decorrer do discurso. Na coesão, ela se apresenta na forma de elementos linguísticos, como a busca por termos análogos, tanto no âmbito semântico quanto 
no pragmático, e por recursos vocabulares, como a elipse, a concordância, etc. Há que se verificar se, no plano conceitual, ocorre a unidade dos elementos e, no plano linguístico, a retomada adequada desses elementos.

A progressão é a retomada dos elementos conceituais acrescidos de informações que adicionem ideias novas ao texto. Tais junções devem agregar valor, de modo que se dê legitimidade ao texto por meio do uso de relações entre o que já foi dito e o que é novo ao discurso. A progressão é tanto um recurso de coerência quanto o desdobramento pela busca de elementos coesivos.

Não contradição significa que um texto coerente não pode se contradizer, não pode afirmar uma coisa e então refutá-la. Ele tem de respeitar proposições legítimas sem conflito de ideias, tanto quanto ser habitável ao universo no qual está inserido, isso significa ser condizente com o que se propõe, tanto nas situações quanto no momento determinado pelo texto. Uma reação inversa - a contradição - só pode ser considerada e aplicada em razão de intenção própria, senão prejudica a interpretação do recebedor ao se desvirtuar do intento primário.

A articulação determina se as ideias do texto estão interligadas. Refere-se ao uso de recursos formais para expressar as relações de fatos e conceitos entre si, bem como para instaurar sentido no plano lógico-semântico-conceitual.

Portanto, há que se considerar sempre, para a análise textual, os aspectos coesivos e coerentes do texto como dois aliados no processo formador de sentido. Como afirma Fávero, para

[...] chegar à compreensão do texto como um todo coerente, é necessário que sejam trabalhadas não só as relações coesivas (a coesão é decorrência da coerência e a concatenação linear não é garantia de um texto coerente), mas, e principalmente, as de conexão conceitual-cognitiva (2006, p. 77).

Desse modo, desvincular a coesão da coerência não condiz com a lógica da interpretabilidade, que pretende aproximar esses dois elementos produtores de sentido, unindo-os de maneira que cada um ocorra por si, todavia intrinsecamente ligados. Partindo desse pressuposto, este trabalho buscou referências que indicassem uma análise textual de maneira global, em que, teoricamente, os elementos constitutivos produtores de sentido do texto estivessem imbricados de tal maneira que não se fizesse distinção entre os aspectos de coesão e coerência e sem prejuízo quanto à qualidade e à atribuição de valor para tais análises.

Assim, chegou-se a Charolles (2002), que não distinguiu coesão de coerência e, por isso, não delimitou o espaço de cada um desses aspectos. Ele 
preferiu definir a análise de textos sob a âncora de 4 metarregras de coerência, evidenciando-as nos planos microtextual (a coerência local - frase) e macrotextual (a coerência global - texto ou sequências consecutivas). Sendo assim, para iniciar uma análise de produção textual, ele sugere, primeiramente, que se considere em qual mundo/universo o texto se insere, se faz parte ou não do mundo ordinário. Então, partindo desse pressuposto, podem ser dados os ditames para interpretação, avaliação e posterior julgamento de determinada produção.

A primeira metarregra na qual Charolles se fundamenta é a da repetição, doravante MR1. Para um texto ser coeso e coerente, as relações entre as frases devem obedecer a uma sequência ordenada em suas estruturas e nas sequências consecutivas. Para que isso ocorra, elementos de recorrência escrita são necessários. A língua dispõe de diversos recursos de repetição que permitem ligar uma frase ou sequência em seu contexto imediato, retomando constituintes de modo a interligar e estabelecer conexões de desenvolvimento linear entre elas. Esses recursos são encontrados nas pronominalizações, nas substituições lexicais, nas recuperações pressuposicionais e nas retomadas de inferências, como nos exemplos que seguem:

(1) Uma velhinha foi assassinada na semana passada em Campinas. $(<=)$ Ela foi encontrada estrangulada na banheira.; (2) 'Vou confessá-lo (=>): este crime me perturbou.'; (3) 'Picasso morreu faz um ou dois anos. O artista deixou sua coleção pessoal para o museu de Barcelona.' (CHAROLLES, 2002, p. 50, 53).

Observa-se que as palavras destacadas em itálico denotam a substituição lexical e a pronominalização em um caso de reiteração do que já tinha sido mencionado anteriormente.

A segunda metarregra é a da progressão, doravante MR2. Segundo essa metarregra, o texto necessita, em seu desenvolvimento, de contribuição semântica a fim de evitar que este se volte para si mesmo e assim ocorra a circularidade do assunto: "[...] é preciso que haja no seu desenvolvimento uma contribuição semântica constantemente renovada" (CHAROLLES, 2002, p. 58). O autor ressalta a importância da continuidade temática e a progressão semântica, as quais estão intimamente ligadas às MR1 e MR2.

Informações inéditas no texto podem causar uma despolarização nas ideias de modo que, quando um texto apresenta mais de uma série de temas dignos de aprofundamento, é necessário que cada série apresente, na superfície, conjuntos sequenciais homogêneos, portanto, um alinhamento entre hipertemas, para que 
se promova a linearização e a inserção desses hipertemas sem que isso acarrete prejuízos ao sentido do texto.

Segue o exemplo de uma redação e da correção de um texto, na qual se fazia necessária a progressão semântica, apresentada por Charolles (2002). O tema proposto aos alunos foi que descrevessem uma foto que representava um ferreiro trabalhando.

(1) 'O ferreiro está vestido com uma calça preta e um chapéu claro com um paletó cinza e marrom escuro. Tem na mão a ponta da picareta e bate em cima com um martelo, sobre a ponta da picareta. Os gestos que fez, tem a ponta da picareta e com seu martelo bate sobre a pinta da picareta. A ponta desta ferramenta que se chama a ponta da picareta é pontuda e a outra ponta é quadrada. Para tornar ela vermelha com a ponta da picareta colocou ela no fogo e as mãos estão vermelhas.' (texto original)

(2) 'O ferreiro está vestido com uma calça preta, com um chapéu marrom claro e com um paletó cinza escuro. Tem na mão a ponta da picareta e bate em cima com um martelo. A ponta desta ferramenta é pontuda e a outra extremidade é quadrada. Para torná-la vermelha, colocou-a no fogo e as mãos estão vermelhas.' (texto corrigido) (CHAROLLES, 2002, p. 59).

A evidente circularidade no texto original denota a baixa contribuição de informações, o que o torna fundamentalmente inaceitável, mesmo que não esteja totalmente desprovido de coerência. Recursos progressivos e de novidade semântica fazem-se necessários de modo programado e quando a sequência dos elementos se apresenta de maneira ordenada.

A terceira metarregra de Charolles é a da não contradição (MR3). Essa metarregra prevê que não haja elemento semântico que possa contradizer um conteúdo posto ou pressuposto em ocorrência anterior no desenvolvimento textual. $\mathrm{O}$ pesquisador dividiu a análise da não contradição em 3 tipos de contradições, que geralmente se apresentam nas produções textuais. Tanto quanto ocorrências distintas, elas estão intrinsecamente ligadas e analisá-las individualmente compete considerar as demais.

As contradições enunciativas determinam que toda manifestação textual possui um sistema de referência temporal, que instaura o modo de funcionamento do discurso. No exemplo a seguir (CHAROLLES, 2002, p. 61), não há como precisar essa referência temporal, o que faz com que as sequências compostas se desvirtuem e sejam incoerentes: "Antônio sai para um passeio 
com o Sr. Esnobe. Chegando perto de uma árvore, nós paramos para conversar. Francisco e Julia querem jogar um jogo".

As contradições inferenciais e proposicionais dão-se quando incompatibilidades semânticas profundas sobrevêm e prejudicam a compreensão do texto. Os exemplos que seguem trazem casos desses desvios semânticos e são facilmente observáveis (CHAROLLES, 2002, p. 64): (1) "Minha tia é viúva. Seu marido coleciona máquinas de costura."; (2) "Pedro não tem carro. Vai vender o dele para comprar um novo".

As contradições de mundo e de representações do mundo não podem ser explicadas no campo linguístico, somente no que compete às noções de mundo e de representação tanto do produtor quanto do receptor do texto. Algo incoerente no mundo ordinário torna-se perfeitamente verossímil no plano poético, como o trecho extraído de P. Clanché (CHAROLLES, 2002, p. 74): "A casa vê uma flor e gostaria muito de apanhá-la. E a flor gostaria muito de apanhar um raio de sol. E o sol dormiu então a flor não pode pegar o raio". Essas contradições referem-se às convicções daqueles que participam do ato de comunicação textual, ou seja, uma contradição pode ser proposital (nos campos semântico ou pragmático) e absolutamente aceitável/compreensível para o receptor, porque o jogo de contradições não é um fator de incoerência pelo modo como as representações desse receptor se conduzem.

A quarta e última metarregra de Charolles é a de relação (MR4). A metarregra de relação, em essência, é a que reconhece, primeiramente, o mundo representado em determinado ato de comunicação textual. O texto precisa ser congruente com o mundo denotado, portanto, as recuperações de ideias e retomadas tornam o texto compreensível quando se leva em conta a situação/ plano/mundo ao qual o texto pertence. No exemplo (p. 74), "Maria logo vai dar à luz portanto os cantores românticos desagradam aos intelectuais", vê-se claramente a incoerência de pertinência factual. Portanto,

nos discursos naturais, as relações de relevância factual são geralmente manifestadas por conectores que as explicitam semanticamente [...] a impossibilidade de ligar duas frases por um conector natural é, aliás, um bom teste para revelar uma incongruência [...] (CHAROLLES, 2002, p. 74-75).

Para melhor compreender os aspectos produtores de sentido no texto, segue o Quadro 1, no qual foram desmembrados os elementos coesivos de coerência e pragmáticos na atividade textual, conforme Charolles (2002). 


\begin{tabular}{|c|c|c|c|}
\hline Critério & $\begin{array}{l}\text { Subdivisão do } \\
\text { critério }\end{array}$ & Tópicos a considerar & Tópicos a analisar \\
\hline Coerência & & \multirow{2}{*}{$\begin{array}{l}\text { Continuidade } \\
\text { Progressão } \\
\text { Não contradição } \\
\text { Articulação }\end{array}$} & \multirow{2}{*}{$\begin{array}{l}\text { Metarregras de: } \\
\text { repetição; progres- } \\
\text { são; não contradição } \\
\text { e relação }\end{array}$} \\
\hline Coesão & $\begin{array}{l}\text { Reiteração, substi- } \\
\text { tuição e associação }\end{array}$ & & \\
\hline Intencionalidade & & $\begin{array}{l}\text { Valor ilocutório do } \\
\text { discurso }\end{array}$ & \\
\hline Aceitabilidade & & $\begin{array}{l}\text { Se é passível de recep- } \\
\text { tividade }\end{array}$ & \\
\hline Situacionalidade & & $\begin{array}{l}\text { Se é adequado para } \\
\text { determinada situação } \\
\text { comunicativa }\end{array}$ & \\
\hline Informatividade & $\begin{array}{l}\text { Imprevisibilidade e } \\
\text { suficiência de dados }\end{array}$ & $\begin{array}{l}\text { Grau de informativida- } \\
\text { de, novidade }\end{array}$ & \\
\hline Intertextualidade & & $\begin{array}{l}\text { Relação entre o discur- } \\
\text { so e o conhecimento } \\
\text { prévio do recebedor }\end{array}$ & \\
\hline
\end{tabular}

\section{Fonte: Elaborado pelas pesquisadoras.}

Charolles (2002, p. 78-79) deixa claro, em seu trabalho, que as metarregras apresentadas ainda se encontram em processo de desenvolvimento, que a coerência e a análise de textos demandam pesquisa e estudo, para tornar a questão das metarregras um conjunto de regras teoricamente explícitas e controladas, o que justifica a realização deste trabalho.

\section{Metodologia}

Nesta seção, apresenta-se a metodologia utilizada para a realização deste trabalho. A amostra analisada constituiu-se de 8 (oito) textos de 8 (oito) participantes de um curso intitulado "Como começar e como terminar um comentário escrito?", do Projeto de Extensão Lavili - Laboratório de Vivências em Linguagem - Português, da Universidade Feevale/RS. Esses oito participantes foram escolhidos, porque estavam matriculados no ensino superior. E os textos selecionados para a pesquisa foram os primeiros textos redigidos por esses alunos no curso.

O Lavili-Português era um Projeto de Extensão da universidade, cujo objetivo era proporcionar o desenvolvimento da competência discursiva, na 
modalidade escrita, para que, ao qualificar a leitura e a produção de textos, os participantes pudessem interagir com mais facilidade nos diferentes contextos sociais, uma vez que indivíduos mais bem preparados configuram grupos mais desenvolvidos.

O curso "Como começar e como terminar um comentário escrito?" era oferecido a distância, por meio da plataforma virtual Blackboard e exigia dos participantes a realização de tarefas semanais. O projeto contemplava cinco módulos e tinha a duração de 20 horas aula. A cada edição, eram oferecidas 50 vagas, disponibilizadas aos acadêmicos, aos funcionários da instituição e à comunidade em geral, tendo como requisito único ter concluído ou estar concluindo o Ensino Médio.

Para organizar os dados coletados, os participantes e os textos foram identificados conforme segue no Quadro 2.

\section{Quadro 2 - Identificação dos participantes e de seus textos}

\begin{tabular}{|c|c|}
\hline Participante & Tarefa 1 \\
\hline A & A1 \\
\hline B & B1 \\
\hline C & C1 \\
\hline D & D1 \\
\hline E & E1 \\
\hline F & F1 \\
\hline G & G1 \\
\hline H & H1 \\
\hline
\end{tabular}

Fonte: Elaborado pelas pesquisadoras.

Cabe destacar que, em momento algum, pretendeu-se analisar as produções com o intuito de avaliar ou julgar a qualidade da escrita dos participantes, houve interesse somente em verificar se havia inadequação nas produções textuais no que tange aos aspectos de coesão e coerência. Em função disso, não foram identificados aspectos de pontuação e ortografia, entre outros aspectos gramaticais que pudessem configurar erro. 
Após a seleção e a identificação dos textos, passou-se à sua leitura e análise. A análise dos textos foi realizada com base no quadro das metarregras propostas por Charolles (2002), conforme está estabelecido no Quadro 3 que segue.

\section{Quadro 3 - Síntese dos critérios de análise}

\section{Metarregra de repetição -MR 1}

Elementos de recorrência estrita:
a) as pronominalizações;
b) as definitivações e as referenciações dêiticas contextuais;
c) as substituições lexicais;
d) as recuperações pressuposicionais e as retomadas de inferência.

\section{Metarregra de progressão - MR 2}

a) continuidade temática;

b) progressão semântica (articulação tema/rema).

\section{Metarregra de não contradição - MR 3}

a) contradições enunciativas;

b) contradições inferenciais e pressuposicionais;

c) mundo(s), representações do mundo (e dos mundos) e contradição.

\section{Metarregra de relação - MR 4}

a) ações, estados ou eventos que determinada sequência apresenta e que tem de ser congruente com o mundo reconhecido por quem a recebe.

\section{Fonte: Elaborado pelas pesquisadoras.}

Depois da análise dos textos, todas as inadequações localizadas foram categorizadas de acordo com o Quadro 3, por participante e por texto, e, para facilitar a visualização, os resultados foram apresentados por meio de quadros, que são apresentados na seção que segue. Os dados desses quadros foram discutidos à luz da revisão teórica realizada.

\section{Apresentação e discussão dos resultados}

Nesta seção, são apresentados e discutidos, à luz da revisão teórica realizada, os dados coletados por meio das análises dos textos selecionados para este trabalho. Para tanto, apresentam-se, a seguir, as atividades de cada participante 
e um quadro-síntese com as inadequações identificadas no que diz respeito às metarregras, tomando-se como base o Quadro 3, além de uma breve análise dos resultados, e, na sequência, uma análise geral dos resultados.

Para uma melhor visualização, foi elaborado um quadro-resumo para cada texto. Os textos com as marcações dos aspectos analisados encontram-se nos anexos.

\begin{tabular}{|l|l|}
\multicolumn{1}{|c}{ Quadro 4 - Síntese dos erros do aluno A - texto A1 } \\
\hline METARREGRAS & $\begin{array}{l}\text { TEXTO 1 } \\
\text { MR1 } \\
\text { lugar de "a"; pronominalização inadequada no uso do pronome "seu" na } \\
\text { linha 8, que não possui referente. } \\
\text { (b) falta de definitivização de "uma criança" da linha 1 nas linhas 3 e 5. } \\
\text { (c) Recorrência excessiva da palavra "leitura" (linhas 1, 4 e 4); re- } \\
\text { corrência excessiva da palavra "mundo" (linhas 4, 5 e 7); recorrência } \\
\text { excessiva da palavra "crianças" (linhas 2, 3, 5 e 5). }\end{array}$ \\
\hline MR2 & $\begin{array}{l}\text { Na frase: "Para uma criança que lê, as palavras ganham sentido com } \\
\text { maior rapidez incrível, além de entender mais sobre o mundo que o } \\
\text { cerca, compreendendo regras da escola com maior facilidade, parti- } \\
\text { cipando das aulas com maior entusiasmo e demonstrando seu conhe- } \\
\text { cimento que trazem dos livros", observa-se quebra da continuidade } \\
\text { temática. }\end{array}$ \\
\hline MR3 & $\begin{array}{l}\text { Observa-se inobservância da MR4 na frase: "Para uma criança que } \\
\text { lê, as palavras ganham sentido com maior rapidez incrível, além de } \\
\text { entender mais sobre o mundo que o cerca, compreendendo regras da } \\
\text { escola com maior facilidade, participando das aulas com maior en- }\end{array}$ \\
\hline $\begin{array}{l}\text { tusiasmo e demostrando seu conhecimento que trazem dos livros", } \\
\text { uma vez que a leitura, entendida como um mundo de imaginação, não } \\
\text { implica na compreensão das regras da escola. }\end{array}$ \\
\hline MR4
\end{tabular}

\section{Fonte: Elaborado pelas pesquisadoras.}

Observando-se o Quadro 4, verifica-se que o aluno A apresentou seis ocorrências de desvio de MR1; uma ocorrência de desvio de MR2; nenhum desvio de MR3; e um de MR4. 


\section{Quadro 5 - Síntese dos erros do aluno B - texto B1}

\begin{tabular}{|c|l|}
\hline METARREGRAS & \multicolumn{1}{c|}{ TEXTO 1 } \\
\hline MR1 & $\begin{array}{l}\text { (a) pronominalização inadequada no uso do pronome "le" na linha 2 no } \\
\text { lugar de "a criança", quando o correto seria usar o pronome "a". } \\
\text { (b) na linha 3, em "criem o hábito de usá-los criando assim um vin- } \\
\text { culo", o verbo "criar" utilizado duas vezes sobrecarrega a sentença de } \\
\text { retomadas de lexemas. } \\
\text { (c) na linha 3, há uma retomada de inferência inadequada: o verbo } \\
\text { "criem" (elipse do pronome) não concorda em número com a referente } \\
\text { "a criança" da linha 1. }\end{array}$ \\
\hline MR2 & $\begin{array}{l}\text { (a) na linha 1, em: "para olhar figuras e relacioná-las", observa-se } \\
\text { quebra da continuidade temática, uma vez que a relação estabelecida na } \\
\text { frase não é de finalidade. } \\
\text { (b) na linha 3, em "faz com *criem o hábito", há falta de progressão } \\
\text { semântica em função da falta do articulador "que". }\end{array}$ \\
\hline MR3 & \\
\hline MR4 & \\
\hline
\end{tabular}

\section{Fonte: Elaborado pelas pesquisadoras.}

A análise do Quadro 5 revela que o aluno B não apresentou desvios nas MR3 e MR4, contudo teve um elevado número de desvios de MR1 e MR2. O texto B1 é um exemplo do que aborda a proposta de Charolles (2002), quando afirma que não se desvincula coesão e coerência em um texto, pois a produção em questão está estruturalmente correta, mas não apresenta sequenciação e tampouco progressão semântica. O texto caracterizou-se pela falta de referenciação dêitica contextual, pois algumas expressões e alguns trechos não possuem ligação alguma com outras partes do texto.

\section{Quadro 6 - Síntese dos erros do aluno C- texto C1}

\begin{tabular}{|c|l|}
\hline METARREGRAS & \multicolumn{1}{c|}{ TEXTO 1 } \\
\hline & $\begin{array}{l}\text { (a) na linha 9 há erro de definitivização do artigo indefinido "uma", que, } \\
\text { se substituído por "a", elucidaria o sentido da oração; o pronome indefi- } \\
\text { nido "algo", na linha 5, não possui referenciação dêitica contextual. } \\
\text { (b) recorrência excessiva da palavra "as pessoas", linhas 1, 2, 5 e 6; } \\
\text { (c) houve inadequação da retomada de inferência em "em sua", na } \\
\text { linha 5, pois esta prejudicou o sentido do trecho que veio em seguida: } \\
\text { "consciência". }\end{array}$ \\
\hline MR2 & $\begin{array}{l}\text { Na linha 1 faltou um conector entre "ambientais" e "algo", o que preju- } \\
\text { dicou a progressão semântica da frase. }\end{array}$ \\
\hline
\end{tabular}




\begin{tabular}{|c|l|}
\hline & $\begin{array}{l}\text { (a) nas linhas 6 e 7, em "futuramente viveram", observa-se contradição } \\
\text { enunciativa quando o enunciador conjuga o verbo "viver", equivocada- } \\
\text { mente, no pretérito perfeito, em vez do futuro do presente: "viverão". } \\
\text { (b) Na linha 5 observa-se uma contradição inferencial no trecho "cons- } \\
\text { ciência do mal". }\end{array}$ \\
\hline MR4 & \\
\hline
\end{tabular}

Fonte: Elaborado pelas pesquisadoras.

A análise do Quadro 6 mostra que o aluno C apresentou problemas no desenvolvimento textual, tanto que o texto $\mathrm{C} 1$ apresentou quatro inadequações de MR1, uma de MR2 e duas de MR3. Trata-se de um texto com problemas de repetição/reiteração e de contradições, algo a ser considerado como um indicador de pouca habilidade de escrita.

\section{Quadro 7 - Síntese dos erros do aluno D- texto D1}

\begin{tabular}{|l|l|}
\hline METARREGRAS & \multicolumn{1}{c|}{ TEXTO 1 } \\
\hline & $\begin{array}{l}\text { (a) Há falta de referenciação dêitica contextual na frase das linhas 2 } \\
\text { e 3: "Em função de o material didático, conseguir atrair a atenção e } \\
\text { proporcionar o hábito do livro desde que o princípio", a qual não possui } \\
\text { referente na frase anterior; o mesmo ocorre na frase "Isso possibilita } \\
\text { que a criança..." das linhas 2 e 3, em que o "isso" não possui referente } \\
\text { na frase anterior, tampouco é explicado na sequência do texto; verifica- } \\
\text {-se definitivização inadequada na frase "o raciocínio mais rápido e ana- } \\
\text { lítico" das linhas 5 e 6; inadequação semelhante, é verificada nas linhas } \\
\text { 7 e 8, na frase "o melhor desenvolvimento e crescimento intelectual". } \\
\text { (b) o texto apresenta retomadas excessiva de palavras, como, por exem- } \\
\text { plo: "crianças pequenas", na linha 1; "as crianças", na linha 4, e "as } \\
\text { crianças", na linha 5; em "os livros, na linha 3, "o livro, na linha 4 e "os } \\
\text { livros", na linha 7; e em "o hábito" nas linhas 3, 6 e 7. }\end{array}$ \\
\hline Má falta de progressão temática e de sequenciação semântica na frase: \\
"Em função de o material didático, conseguir atrair a atenção e propor- \\
cionar o hábito do livro desde que o princípio", das linhas 2 e 3;
\end{tabular}

Fonte: Elaborado pelas pesquisadoras.

Analisando-se o Quadro 7, verifica-se que o aluno D teve oito ocorrências de MR1 no texto. Quanto às MR2 e MR3, uma ocorrência para cada MR, e não apresentou desvio de MR4, contudo a repetição excessiva de palavras foi um indicador de pouco recurso de vocabulário do aluno. 


\section{Quadro 8 - Síntese dos erros do aluno E- texto E1}

\begin{tabular}{|c|l|}
\hline METARREGRAS & \multicolumn{1}{c|}{ TEXTO 1 } \\
\hline MR1 & $\begin{array}{l}\text { Recorrência excessiva da palavra "bebê(s)", nas linhas 1, 2, 3, 7 e } \\
8 ; \text { recorrência excessiva da palavra "estímulo" e suas derivadas, nas } \\
\text { linhas 1, 2, 3 e 5. }\end{array}$ \\
\hline MR2 & \\
\hline MR3 & $\begin{array}{l}\text { (a) Há uma contradição enunciativa em "estabelece-se", linha 8, pois a } \\
\text { palavra empregada está inadequada ao contexto. } \\
\text { (b) na linha 3 há a afirmação de que os bebês leem, porém os bebês } \\
\text { são estimulados pelos pais, que leem para os filhos. }\end{array}$ \\
\hline MR4 & \\
\hline
\end{tabular}

\section{Fonte: Elaborado pelas pesquisadoras.}

O aluno E, como mostra o Quadro 8, apresentou poucos erros na escrita, porém, teve desvio na MR1, que se deve ao número expressivo de repetições de palavras, o que ocasionou recorrência excessiva e, por conseguinte, prejudicou a progressão semântica. Pôde-se observar, ainda, que o aluno apresentou somente duas contradições de MR3.

\section{Quadro 9 - Síntese dos erros do aluno F- texto E1}

\begin{tabular}{|c|l|}
\hline METARREGRAS & \multicolumn{1}{c|}{ TEXTO 1 } \\
\hline MR1 & Na linha 14 houve falta de definitivização em "gosto". \\
\hline MR2 & $\begin{array}{l}\text { Nas linhas 11 e 12, em "RBS TV "A educação precisa de respostas", } \\
\text { faltou contribuição lexical entre "RBS TV 'A educação...", para que } \\
\text { haja ligação entre o idealizador do projeto e o projeto em si. Uma } \\
\text { sugestão para isso seria: "RBS TV com a campanha "A educação...". }\end{array}$ \\
\hline MR3 & \\
\hline MR4 & \\
\hline
\end{tabular}

Fonte: Elaborado pelas pesquisadoras.

A análise do Quadro 9 mostra que o aluno $\mathrm{F}$ apresentou poucos erros e, pelo seu vocabulário e pelo recurso argumentativo utilizado no texto F1, percebe-se que o enunciador é um indivíduo com uma boa proficiência de leitura, pois cita nomes de autores e faz comparações com propriedade. 


\section{Quadro 10 - Síntese dos erros do aluno G - texto G1}

\begin{tabular}{|c|l|}
\hline METARREGRAS & \multicolumn{1}{c|}{ TEXTO 1 } \\
\hline & $\begin{array}{l}\text { (a) pronominalização inadequada no uso do pronome "estes" e da } \\
\text { palavra "formam", na linha 2, que não concordam com o referente: } \\
\text { "ser humano", na linha 1; na linha 2, a palavra "nesta" está aplicada } \\
\text { de maneira incorreta, o correto seria "esta"; na linha 3, o pronome } \\
\text { "ela" é um recorrente desnecessário, pois, no início da frase, já se } \\
\text { tem: "Nesta fase é de grande importância"; as palavras: "pequenas", } \\
\text { "mostrar-lhes", "contar-lhes" e "nelas", nas linhas 8 e 9, não concor- } \\
\text { dam com o referente, "a criança", em número; na linha 12, a defini- } \\
\text { tivização em "a possibilidade" prejudicou a localização do referente, } \\
\text { caso em que a pronominalização "sua", para retomar "essa", na linha } \\
\text { anterior, seria mais apropriada. } \\
\text { (b) faltou definitivização nas palavras "curiosidade" e "prazer", na } \\
\text { linha 10; ocorreu definitivização inadequada em: "essa criança", na } \\
\text { linha 11, que pode ser substituída pelo artigo "a criança". }\end{array}$ \\
\hline MR2 gerúndio em, "facilitando assim a ter uma", na linha 7, causa que- \\
bra de sequenciação e continuidade temática.
\end{tabular}

Fonte: Elaborado pelas pesquisadoras.

Analisando-se o Quadro 10, verifica-se que o aluno G apresentou sete erros de MR1. Apesar do alto número de desvios de MR1, trata-se de um texto conciso e relativamente bem articulado. Observou-se que o uso inadequado do gerúndio acarretou a quebra da progressão e da sequenciação temática.

\section{Quadro 11 - Síntese dos erros do aluno H- texto H1}

\begin{tabular}{|l|l|}
\hline METARREGRAS & \multicolumn{1}{c|}{ TEXTO 1 } \\
\hline \multirow{3}{*}{ MR1 } & $\begin{array}{l}\text { (a) na linha 10, "esses ingênuos bebês", não possui referenciação } \\
\text { dêitica contextual pelo fato de que "esses bebês" não aparecem antes } \\
\text { e tampouco após essa ocorrência; faltou definitivização em "nossa", } \\
\text { na linha 11. } \\
\text { (b) nas linhas 1, 2, 8 e 10, há retomada excessiva da palavra } \\
\text { "bebê(s)"; o mesmo ocorre nas linhas 1, 3 e 8 com a palavra "leitura"; } \\
\text { e com as palavras "incentivo", linhas 1 e 7, e sua derivada "incentiva- } \\
\text { dos", na linha 9. }\end{array}$ \\
\hline
\end{tabular}




\begin{tabular}{|l|l|}
\hline & $\begin{array}{l}\text { (a) na linha 5 há inadequação de continuidade temática em "em", } \\
\text { o que limita a progressão semântica, se substituído por "para o", se } \\
\text { estabeleceria a relação apropriada. } \\
\text { (b) na linha 8, "sendo que podemos", há a falta de elemento de pro- } \\
\text { gressão semântica, um finalizador, como por exemplo, "portanto" e, } \\
\text { se a intenção é projetar para o futuro tal ideia, "podemos ter grandes", } \\
\text { na mesma linha, há que se se colocar o verbo também no futuro: } \\
\text { "poderemos". }\end{array}$ \\
\hline MR3 & \\
\hline MR4 & \\
\hline
\end{tabular}

\section{Fonte: Elaborado pelas pesquisadoras.}

A análise do Quadro 11 revelou que o aluno $\mathrm{H}$ apresentou cinco erros de MR1 e dois de MR2. Mesmo com um número expressivo de desvio de MR1, o texto apresentou estrutura concisa e fácil interpretação.

Comparando-se as produções dos participantes, pode-se dizer, em síntese, que ficou evidente a necessidade de esses alunos realizarem atividades para desenvolver sua competência discursiva, mesmo que a maioria dos textos tenham apresentado poucos problemas.

Fazendo-se uma análise geral, pode-se dizer que o expressivo número de desvios da MR1 em todas as produções sugere que os participantes possuem dificuldades de identificar, no próprio texto, aspectos de recorrência estrita. Os alunos parecem desconhecer os recursos que podem ser usados para evitar as repetições, o que acarreta prejuízo à progressão semântica e à contribuição temática em suas produções.

Excluindo-se os textos B1 e H1, todos os demais apresentaram muitos problemas quanto à MR2, ou seja, no quesito progressão do texto. Acredita-se que isso se deva ao fato de os participantes terem tido índices altos nos desvios da MR1.

Das oito produções analisadas, quatro não apresentaram desvios de MR3, o que significa um aspecto bastante positivo. Observou-se que, em alguns casos, quando ocorreu contradição nos textos, ela se deu em função do uso inadequado de alguns verbos, o que resultou em equívoco, principalmente, quanto ao tempo verbal. A troca de "ão" por "am" em verbos que, contextualmente, deveriam estar na terceira pessoa do plural no futuro do presente, acarretou contradição.

Somente o texto A1 apresentou desvio da MR4. Pode-se atribuir isso ao fato de que as propostas textuais se encontravam delimitadas a determinados temas, que não permitiam situações hipotéticas, em função disso não era possível abrir precedentes em relação ao mundo apresentado. 
O Quadro 12, a seguir, apresenta a síntese dos desvios verificados nos textos analisados com relação às metarregras.

Quadro 12 - Síntese dos resultados

\begin{tabular}{|c|c|c|c|c|}
\cline { 1 - 2 } MR & $\begin{array}{c}\text { Metarregra 1 } \\
\text { Repetição }\end{array}$ & $\begin{array}{c}\text { Metarregra 2 } \\
\text { Progressão }\end{array}$ & $\begin{array}{c}\text { Metarregra 3 } \\
\text { Não contradição }\end{array}$ & $\begin{array}{c}\text { Metarregra 4 } \\
\text { Relação }\end{array}$ \\
\cline { 1 - 2 } A1 & 6 & 1 & 0 & 1 \\
\hline B1 & 3 & 2 & 2 & 0 \\
\hline C1 & 3 & 1 & 1 & 0 \\
\hline E1 & 8 & 1 & 2 & 0 \\
\hline F1 & 1 & 1 & 0 & 0 \\
\hline G1 & 7 & 1 & 1 & 0 \\
\hline H1 & 5 & 2 & $\mathbf{6}$ & $\mathbf{1}$ \\
\hline TOTAL & $\mathbf{3 3}$ & $\mathbf{9}$ & & 0 \\
\hline
\end{tabular}

Fonte: Elaborado pelas pesquisadoras.

A comparação entre os resultados da pesquisa mostra que os erros de MR1 e MR2 são os mais recorrentes. Isso provavelmente se dá em função da carência de recursos de vocabulário e de argumentação dos alunos, o que pode decorrer do baixo investimento em leitura.

Por fim, cabe dizer que esse resultado mostra que pouco se tem evoluído no que diz respeito a problemas de coesão e coerência, isso porque, possivelmente, apesar das mudanças que vêm ocorrendo no ensino da língua materna, a escola pouco tem feito para qualificar a produção escrita de seus alunos.

\section{Considerações finais}

Uma pesquisa é pertinente quando ancorada em fundamentos relevantes e que denota carência de estudos em determinados assuntos. A partir desse pressuposto, aliado à curiosidade epistemológica acerca dos estudos linguísticos, este trabalho buscou pesquisar e compreender o complexo processo de produção textual.

Por meio da pesquisa teórica, ficou claro que inúmeras vertentes procuram esclarecer sobre e estabelecer diretrizes para as teorias do texto, porém, por 
tratar-se de um objeto de uso e interpretação múltiplos e porque dele derivam incontáveis ramificações sociais, culturais e interacionais, entender como o texto funciona mostrou-se uma tarefa deveras complexa.

A pesquisa desenvolvida neste estudo buscou verificar, com referentes que pudessem ser válidos para a análise de textos, a coesão e a coerência em textos de universitários matriculados no curso "Como começar e como terminar um comentário escrito?" do Projeto do Lavili-Português, da Universidade Feevale/RS, se os textos desses alunos apresentavam boa articulação, de modo que configurassem bons textos.

A análise dos textos revelou que todos eles apresentaram algum tipo de desvio de metarregra, não que isso seja indício de um mau texto, contudo, mostra que é necessário investir mais em atividades de produção textual e de reescrita. Cabe salientar que alguns textos estão bem estruturados e articulados. O que ocorreu, contudo, em todos os textos, foi o desvio da MR1, que é primária no que toca à desenvoltura na escrita, pois depende da MR1 estabelecer as ligações que vão dar continuidade e sentido ao texto.

No que diz respeito ao objetivo geral estabelecido para este trabalho, que era verificar se as produções textuais de alunos de ensino superior realizadas em um curso de extensão da Universidade Feevale, direcionado ao desenvolvimento da competência discursiva, contemplavam os aspectos essenciais que um texto deve apresentar para ser bem compreendido, pode-se dizer que todos os textos analisados se mostraram compreensíveis, apesar de apresentarem muitas inadequações em relação às metarregras investigadas.

Quanto aos objetivos específicos, concluiu-se que os textos analisados apresentam tanto problemas de coesão quanto de coerência, os quais não foram separados, considerando-se que o estudo foi baseado em Charolles (2002), segundo o qual não convém separar um processo do outro, já que um implica o outro. No que tange aos problemas mais recorrentes, de acordo com a teoria das metarregras de coerência de Charolles (2002), verificou-se maior incidência de problemas relativos à MR1, o que pode estar relacionado à falta de leitura e ao pouco exercício de atividade escrita.

É importante ressaltar que o projeto de extensão oportunizou atividades de reescrita e atendimento para a solução de dúvidas dos participantes dos cursos. Portanto, não se pode certificar que as produções não foram satisfatórias por incúria do projeto, mas sugerir que este amplie suas atividades para tentar auxiliar os participantes a dirimirem suas dificuldades.

Esta pesquisa tornou evidente algo que há muito tempo preocupa os professores: o mau desempenho dos alunos em produções escritas, mesmo 
no ensino superior, período em que se espera que os conhecimentos relativos à língua materna sejam mais amplos, pois os textos analisados revelaram um desempenho inferior ao esperado para esse grupo, que é levado para a vida acadêmica e, por conseguinte, para a profissional.

Por tudo isso, independentemente da proposta do Lavili-Português, é de importância capital que as pessoas procurem meios de aperfeiçoar seu desempenho na comunicação escrita, pois, nesse caso, sendo membros da comunidade acadêmica, faz-se mister o bom uso da linguagem e uma produção textual mais rebuscada.

Esta pesquisa deixou clara a necessidade de se buscar aprimoramento, tanto dos que participam dos cursos quanto do Projeto Lavili-Português que, em sua gestão, poderia ter ampliada a capacidade para receber mais alunos e também desenvolver subsídios para melhorar seus cursos, oportunizando, assim, a aprendizagem daqueles que desejam e necessitam ampliar seus conhecimentos.

Uma investigação mais ampla, que abranja as razões pelas quais ainda se observa tamanha quantidade de erros na escrita e em membros da comunidade acadêmica, bem como as implicações de se escrever um bom texto no que toca ao acesso a grupos sociais mais desenvolvidos podem vir a ser tema de futuras pesquisas.

\section{Referências}

AUSTIN, J. L. Outras mentes. In: Col. Os Pensadores. 2. ed. São Paulo, SP: Abril Cultural, 1985.

CHAROLLES, Michel. Introdução aos problemas da coerência dos textos (Abordagem teórica e estudo das práticas pedagógicas). In: GALVES, C. (Org.) O texto: leitura e escrita. 3. ed. Campinas, SP: Pontes, 2002. p. 39-90. FÁVERO, Leonor Lopes; KOCH, Ingedore G. Villaça. Linguística textual: uma introdução. 7. ed. São Paulo, SP: Cortez, 2005.

FÁVERO, Leonor. Coesão e coerência textuais. 11. ed. São Paulo, SP: Ática, 2006.

KOCH, Ingedore Grunfeld Villaça. A coesão textual. 11. ed. São Paulo, SP: Contexto, 1999.

KOCH, Ingedore Grunfeld Villaça. O texto e a construção dos sentidos. 4. ed. São Paulo, SP: Contexto, 2000, p. 11-25.

$\mathrm{KOCH}$, Ingedore Grunfeld Villaça. Desvendando os segredos do texto. 2. ed. São Paulo, SP: Cortez, 2003. 


\section{KOCH, Ingedore Grunfeld Villaça; TRAVAGLIA, Luiz Carlos. Texto e coe- rência. 6. ed. São Paulo, SP: Cortez, 1999. \\ KOCH, Ingedore Grunfeld Villaça; TRAVAGLIA, Luiz Carlos. A coerência textual. 16. ed. São Paulo, SP: Contexto, 2004. \\ VAL, Maria da Graça Costa. Redação e Textualidade. 2. ed. São Paulo, SP: Martins Fontes, 1999.}

ANEXOS
Aluno A - Atividade 1
\begin{tabular}{|l|l|}
\hline 01 & A leitura deve ser incentivada por pais e professores. Portanto, uma criança que chega \\
02 & na escola com o hábito de ouvir histórias contadas pelos pais em casa, já trazem con- \\
03 & sigo uma bagagem muito maior que um criança que não teve contato com o mundo da \\
04 & leitura. A leitura, é um incentivo para a imaginação das crianças, um mundo de cores e \\
05 & magia. Para uma criança que lê, as palavras ganham sentido com maior rapidez incrí- \\
06 & vel, além de entender mais sobre o mundo que $\underline{o}$ cerca, compreendendo regras da escola \\
07 & com maior facilidade, participando das aulas com maior entusiasmo e demostrando seu \\
08 & conhecimento que trazem dos livros. \\
\hline
\end{tabular}

\section{Aluno B - Atividade 1}

\begin{tabular}{|l|l|}
\hline 01 & Estimular à criança a gostar dos livros desde muito cedo *para olhar figuras e relacioná- \\
02 & -las com o mundo que Le cerca aumenta sua curiosidade ao mesmo tempo em que faz \\
03 & com * criem o hábito de usá-los criando assim um vinculo entre ambos que seguira com \\
04 & ela por toda a sua vida. Dessa forma ela acabam desenvolvendo cada vez mais rápido \\
05 & sua capacidade de ler, escrever e fazer uso da linguagem corretamente. \\
\hline
\end{tabular}

\section{Aluno C - Atividade 1}

\begin{tabular}{|l|l|}
01 & A presente leitura apresenta uma serie de inovações que se iniciam na infância, as \\
02 & tecnologias se aprimoram e as crianças apresentam uma melhor evolução de aprendi- \\
03 & zado. O presente texto mostra que toda criança tem a capacidade de aprendizado muito \\
04 & mais equivocada, quando testadas e ensinadas desde cedo, a família seria a palavra \\
05 & chave nesta composição e as tecnologias e modernidades aprimoram estas situações. \\
06 & Toda criança desenvolve capacidades mais equivocadas se treinadas ensinadas desde \\
07 & cedo, a tecnologia anda junto com estes desenvolvimentos e gera um melhor fluxo neste \\
08 & ensinamento em certo ponto porém, o velho método do livro não pode ser substituído \\
09 & de forma alguma, onde entra a importância da família no aprendizado destas crianças.
\end{tabular}




\section{Aluno D - Atividade 1}

\begin{tabular}{|l|l|}
\hline 01 & A leitura direcionada para crianças pequenas, permite que, elas se desenvolvam mais \\
02 & rápido. Em função de o material didático, conseguir atrair a atenção e proporcionar o \\
03 & hábito do livro desde que o princípio. Isso possibilita que a criança já tenha o convívio \\
04 & com os livros, *mesmo que ele não contenha muitas palavras. Por fim, pode-se destacar \\
05 & que as crianças desenvolvem o raciocínio mais rápido e analítico em virtude do hábito \\
06 & da leitura. Portanto, é possível, afirmar que o hábito e o convívio com os livros permite \\
07 & o melhor desenvolvimento e crescimento intelectual nas crianças. \\
\hline
\end{tabular}

\section{Aluno E - Atividade 1}

\begin{tabular}{|l|l|}
01 & Bebês estimulados desenvolvem-se melhor. Em primeiro lugar, uma forma de in- \\
02 & centivar a estimulação de bebês se dá através da prática da leitura, pois os bebês que \\
03 & praticam a leitura recebem mais estímulos favoráveis ao aperfeiçoamento de sua comu- \\
04 & nicação. Em seguida, a convivência com animais de estimação é outro estímulo eficaz, \\
05 & porque traz as noções de cuidados e responsabilidades em relação ao outro. Ou seja, \\
06 & estas duas práticas proporcionam ao bebê bom uso da linguagem e boa postura social. \\
07 & Dessa forma, estabelece-se que a leitura e a convivência com animais de estimação são \\
08 & duas práticas fundamentais para um desenvolvimento favorável do bebê. \\
\hline
\end{tabular}

\section{Aluno F - Atividade 1}

\begin{tabular}{|l|l|}
\hline 01 & "Não sei por que precisamos ler machado de Assis para prestar o vestibular, ele é um \\
02 & autor chato, com uma forma de escrever dificil de se entender. Por que não pediram \\
03 & para lermos autores mais fáceis, tipo Paulo Coelho?" Assim mesmo, dessa forma, foi \\
04 & o depoimento de uma vestibulanda sobre a leitura exigida para prestar o vestibular. E \\
05 & desse depoimento surge uma pergunta, ou ainda, uma análise a ser feita. Machado de \\
06 & Assis, Olavo Bilac, Carlos Drumond de Andrade, Graciliano Ramos, e tantos outros \\
07 & dos nossos grandes poetas, são realmente enfadonhos e difíceis de serem lidos? A \\
08 & resposta provavelmente será sim. Paulo Coelho, J. K. Rollings, E. L. James são mais \\
09 & fáceis de lerem? A resposta provavelmente será não. Mas será mesmo? Essa questão \\
10 & está sendo levantada pela RBS TV “A educação precisa de respostas", e de uma forma \\
11 & bem interessante. Personagens da nossa literatura tentam despertar nas crianças o gosto \\
12 & e o hábito pela leitura, e subsequentemente, (o) gosto pelo estudo. É de pequeno que se \\
13 & adquire o hábito da leitura e do estudo. Ler é educar? Com certeza. Machado de Assis \\
14 & e todos os outros imortais são uma leitura difícil? Nem tanto. "A educação precisa de \\
15 & respostas" é uma resposta a estes questionamentos, não a única, mas um início. \\
\hline
\end{tabular}




\section{Aluno G - Atividade 1}

\begin{tabular}{l|l}
01 & Para que o ser humano tenha gosto pela leitura, este hábito tem que começar na idade \\
02 & em que estes se formam, que é na infância. Nesta fase é de grande importância a leitura \\
03 & porque ela proporciona a capacidade de expressar suas idéias, além do desenvolvimento \\
04 & emocional, social e cognitivo. E é através da literatura infantil, que a criança tem acesso \\
05 & a conhecimentos, recreação, informação e interação necessários ao ato de ler, facilitan- \\
06 & do assim a ter uma visão mais clara do mundo. Mas para isso, tem que haver incentivo, \\
07 & desde pequenas os pais devem mostrar-lhes livros com figuras e contar-lhes histórias \\
08 & infantis, despertando nelas curiosidade e prazer de aprender algo novo a cada frase. \\
09 & Portanto, quando essa criança que teve o hábito de ler desde cedo, se tornar adulta, \\
10 & maior será a possibilidade de ser um leitor crítico, com opinião e que sabe se expressar \\
11 & diante da sociedade. \\
\hline
\end{tabular}

\section{Aluno H - Atividade 1}

01 O incentivo a leitura desde bebê proporciona inúmeras vantagens aos que a praticam.

02 Segundo a reportagem da Revista Nova Escola, os bebês podem até não entender todo

03 o enredo de uma história, mas a leitura em voz alta os coloca em contato com outras

04 dimensões das linguagens oral e escrita, que serão importantes em seu desenvolvimen-

05 to. Especialistas acreditam que para alguém se interessar por livros na vida adulta, é

06 fundamental que a palavra escrita esteja ao seu alcance desde cedo, por isso a impor-

07 tância do incentivo a leitura desde bebê, sabemos que quem lê bem escreve bem, sendo

08 que podemos ter grandes escritores que foram incentivados a partir da infância. É im-

09 portante ressaltar, que esses ingênuos bebês crescerão, e se tornarão adultos, capazes de

10 governar nossa sociedade, então cabe a nós prepará-los para transformar nosso futuro

11 num mundo melhor.

\section{Recebido em 30 de janeiro de 2017.}

Aceito em 18 de abril de 2017. 